\title{
適応離散フーリエ変換法と炎の応用
}

\author{
梅 本 敏 孝*・青 島 伸 治**
}

\section{Adaptive DFT and Its Application}

Toshitaka Umemoto* and Nobuharu Aoshima**

In the previous paper, we proposed an effective spectrum analysis method for transcription, in which adaptive technique was used. Step size parameter of this method is within the range of $0<\mu<\frac{1}{4 L}(L$ : number of weight). But, step size parameter is a convergence factor which determine adaptation rate. If large number of weight is necessary, it limits the adaptation rate. In this reason, we proposed Adaptive DFT by LMS algorithm. By the proposed method, the range of $\mu$ is $0<\mu<\frac{1}{4}$. Simulation and experimental results are illustrated.

Key Words : step size parameter, LMS algorithm, DFT, transcription

\section{1.はじめに}

音声や楽器が奏でる音のようにそのスペクトルが変動 している信号の分析には，短時間スペクトル分析を用い るのが有利である。通常は有限のフレーム長をもつ空関 数で指定した時間範囲の信号を切り出し, FFT 法や MEM 法によってこのようなスペクトル分析を行ってい る ${ }^{1)}$.しかしながら，子音の特徵を抽出しょうとする場合 には，分析フレーム周期が $1 \mathrm{~ms}$ から $2 \mathrm{~ms}$ 程度で，1才 クターブ当たり 100 チャンネル程度の高分解能の分析器 が必要であるといわれている21.このような場合, FFT 法 や MEM 法ではフレームの重複区間が長くなり演算効 率も悪化する。また，フレーム長が分析周波数に関係な く一定となり，中高域の周波数領域では分析周波数に対 して相対的にフレーム長が長くなり特徴が平均化されて しまう.さらに，FFT 法で得られるスペクトルの分析間 隔は一定であり，その中間の周波数成分は補間によって

†第 36 回自動制御連合講演合で発表 $(1992 ・ 10)$

* 筑波大学工学研究科 つくば市天王台 1-1-1

** 筑波大学物理工学系 つくば市天王台 1-1-1

* Graduate School of Engineering, University of Tsukuba, Tsukuba

** Institute of Applied Physics, University of Tsukuba, Tsukuba

(Received July 5, 1993)

(Revised November 1, 1993)
求めなくてはならず，そのため周波数が近い二つ以上の 周波数成分が存在するような信号のスペクトルを求める にはフレーム長を長くしなくてはならず，スペクトルが 変動している信号の分析には向かないことがある.この ようなことから，フレーム長を周波数に依存して変えら れて, 周波数軸上の分析間隔も自由に選択できる短時間 スペクトル分析が要求される.

われわれは周波数軸上の分析間隔も自由に選択できる 短時間スペクトル分析として，LMS アルゴリズムによ る周波数分析法を提案した ${ }^{3)}$. しかし，この周波数分析法 では，取り扱う信号を帯域制限周期波形に限定し求めた ものであり, ステップサイズパラメータ $\mu$ の取り得る範 囲は $0<\mu<\frac{1}{4 L}(L:$ は夕ップ数 $)$ となる ${ }^{4)}$.このため, 上 述のような子音の分析などのように多くのタップ数を必 要とする場合，時間的に変化する信号に対しての追随性 に制限を受けると考えられる。このことから，本論文で はこの周波数分析法を各周波数成分ごとに分割し，各成 分ごとにLMS アルゴリズムを適用した適応離散フーリ 工変換法を提案し, その収束条件を求めるとともに， ス テップサイズパラメータとフレーム長や周波数分解能と の関係を求め，採譜や音声の分析などに有効な周波数分 析法であることを実験によって示す。 


\section{2. 適応離散フーリエ変換法}

$G_{i}$ を周波数成分 $f_{i}$ におけるフーリエ係数とし, $X_{i}(k)$ をつぎのように定義する。

$$
X_{i}(k)=\exp \left(j 2 \pi f_{i} k \Delta T\right)
$$

ここで， $\Delta T$ はサンプリング周期である.また， $G_{i}$ と $X_{i}(k)$ は複素数であり，つぎのように表わす。

$$
\begin{aligned}
& G_{i}=G_{i, R}+j G_{i, J} \\
& X_{i}(k)=X_{i, R}(k)+j X_{i, J}(k)
\end{aligned}
$$

つぎに, 実部のみからなる信号に対するフーリエ係数 $G_{i}$ が複素共役になることを考慮し，Fig. 1 のようなシステ 厶を考えることにする. $d(k)$ を離散フーリエ変換を行い たい信号とすると $i$ 番目の出力 $g_{i}(k)$ との差はつぎのよ うになる。

$$
\begin{aligned}
\epsilon_{i}(k) & =d(k)-g_{i}(k)=d(k)-\left\{G_{i} X_{i}(k)+\bar{G}_{i} \bar{X}_{i}(k)\right\} \\
& =d(k)-2 G_{i, R} X_{i, R}(k)+2 G_{i, J} X_{i, J}(k) \quad(4)
\end{aligned}
$$

この式から, 差の 2 乗平均 $E\left[\epsilon_{i}^{2}(k)\right]$ は文献 3$)$ と同様に $G_{i, J}$ と $G_{i, R}$ についての 2 次式となり， $G_{i, R}$ および $G_{i, J}$ で偏微分することによって最適解 $G_{i}^{*}$ は求まり，つぎの ような離散フーリエ変換の式と等価になる。

$$
G_{i}^{*}=E\left[d(k) \bar{X}_{i}(k)\right]
$$

このように Fig. 1 で示されるシステムによる最適解は 離散フーリエ係数となる。しかし，この方法を用いてス ペクトルを直接的に求めるには, 入力の複素共役 $\bar{X}_{i}(k)$ の時間関数列とフーリエ変換を行いたい信号 $d(k)$ との 相互相関べクトル $E\left[d(k) \bar{X}_{i}(k)\right]$ を求めなくてはなら

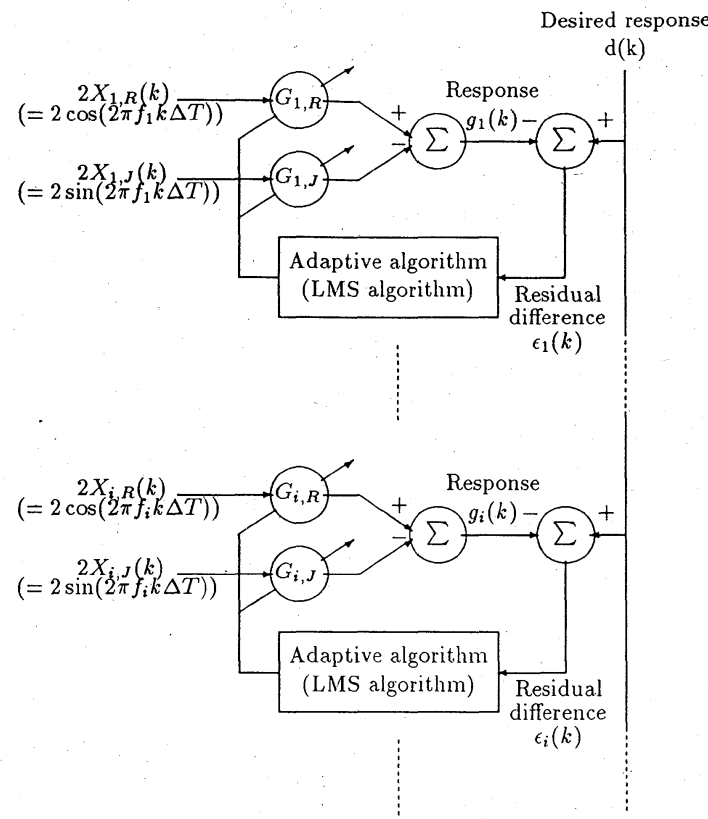

Fig. 1 Adaptive DFT system
ず，多くの計算を必要とし，あまり効果的な方法ではな い.そこで, 本論文でも LMS アルゴリズムを用いること にする. LMSアルゴリズムにおいては， $\epsilon_{i}^{2}(k)$ そのもの を用いて勾配量 $\hat{\nabla}(k)$ を推定し, 負の方向に係数を変化 させるので，つぎのように記述することができる.

$$
\begin{aligned}
G_{i}(k+1) & =G_{i}(k)+\mu_{i}\{-\hat{D}(k)\} \\
& =G_{i}(k)+4 \mu_{i} \epsilon_{i}(k) \bar{X}_{i}(k)
\end{aligned}
$$

ここで, $\mu_{i}$ は $i$ 番目のステップサイズパラメータ(以下 では単にステップサイズパラメータと呼ぶ)である.ま た， $\epsilon_{i}(k)$ はつぎのように表わすことができる.

$$
\begin{aligned}
\epsilon_{i}(k)= & d(k)-g_{i}(k)=d(k) \\
& -\left\{G_{i}(k) X_{i}(k)+\bar{G}_{i}(k) \bar{X}_{i}(k)\right\}
\end{aligned}
$$

\section{3. 適応離散フーリエ変換法の収束安定条件}

適応離散フーリエ変換法は文献 3) で提案した周波数 分析法を各成分ごとに分割し，各成分ごとに LMS アル ゴリズムを適用したものである。このため，収束条件は 文献 4) と同様に集合平均の動的振舞いからしか求める ことができない.

\section{1 係数が収束するための条件}

文献 4) と同様に（7)式を(6)式に代入し，その式につ ぎに定義するような係数とその最適值との差 $C_{i}(k)$ を 代入し, 両辺の期待值をとる.

$$
C_{i}(k)=G_{i}(k)-G_{i}^{*}
$$

一般に $G_{i}(k)$ と $X_{i}(k)$ は独立であると考えられるので， $C_{i}(k)$ と $X_{i}(k)$ も独立であると考えられる，このごとか ら $E\left[C_{i}(k)\right]$ はつぎのようになる。

$$
\begin{aligned}
E\left[C_{i}(k)\right] & =\left(1-4 \mu_{i}\right) E\left[C_{i}(k-1)\right] \\
& =\left(1-4 \mu_{i}\right)^{k} E\left[C_{i}(0)\right]
\end{aligned}
$$

つまりステップサイズパラメータがつぎのような条件を 満たせば, LMS アルゴリズムは収束し, 周波数分析が可 能である。

$$
0<\mu_{i}<\frac{1}{4}
$$

\section{2 学習曲線が収束するための条件}

周波数分析が可能になるだめには係数が収束するとと もに，学習曲線も収束しなくてはならない，そこで，差 の 2 乗平均 $E\left[\epsilon_{i}^{2}(k)\right]$ の動的振舞いから学習曲線が収束 するための条件を求めることにする，まず，初めに差の 2 乗平均の最小值を求める. $i$ 番目の差の 2 乗平均 $E\left[\epsilon_{i}^{2}(k)\right]$ を $\xi_{i, k}$ とおくとその最小值 $\xi_{i, \min }$ はつぎのよ うになる。

$$
\begin{aligned}
\xi_{i, \min } & =E\left[\left\{d(k)-2 G_{i, R}^{*} X_{i, R}(k)+2 G_{i, J}^{*} X_{i, J}(k)\right\}^{2}\right] \\
& =E\left[d(k)^{2}\right]-2\left\{G_{i, R}^{* 2}+G_{i, J}^{* 2}\right\} \\
& =E\left[d(k)^{2}\right]-2 G_{i}^{*} \bar{G}_{i}^{*}
\end{aligned}
$$

文献 3)で提案した周波数分析法では文献 4)で示したよ 
うにパーセバルの定理が成り立ち, 差の 2 乗平均の最小 值 $\xi_{i, \min }$ は零になるが, この方法では零にはならず, 収束 しても(11)式で与えられる差が残る。この式を用いて $\xi_{i, k}$ を求めるとつぎのようになる.

$$
\begin{aligned}
\xi_{i, k}= & E\left[\left\{d(k)-2 G_{i, R}(k) X_{i, R}(k)\right.\right. \\
& \left.\left.+2 G_{i, J}(k) X_{i, J}(k)\right\}^{2}\right] \\
= & E\left[d(k)^{2}\right]-4 E\left[\left\{G_{i, R}^{*} G_{i, R}(k)+G_{i, J}^{*} G_{i, J}(k)\right\}\right. \\
& \left.+2\left\{G_{i, R}^{2}(k)+G_{i, J}^{2}(k)\right\}\right] \\
= & \xi_{i, \min }+2 E\left[G_{i}^{*} \bar{G}_{i}^{*}-2 G_{i}^{*} \bar{G}_{i}(k)-2 G_{i}(k) \bar{G}_{i}^{*}\right. \\
& \left.+2 G_{i}(k) \bar{G}_{i}(k)\right] \\
= & \xi_{i, \min }+2 E\left[C_{i}(k) \bar{C}_{i}(k)\right]
\end{aligned}
$$

このことから, 学習曲線が収束するためにはつぎのよう な条件を満たせばよいということになる。

$$
E\left[C_{i}(k+1) \bar{C}_{i}(k+1)\right]-E\left[C_{i}(k) \bar{C}_{i}(k)\right]<0
$$

この式に(6), (8) 式を代入するとつぎのようになる.

$$
\begin{aligned}
& E\left[C_{i}(k+1) \bar{C}_{i}(k+1)\right]-E\left[C_{i}(k) \bar{C}_{i}(k)\right] \\
&=E\left[\left\{G_{i}(k)+4 \mu_{i} \epsilon_{i}(k) \bar{X}_{i}(k)-G_{i}^{*}\right\}\right. \\
&\left.\times\left\{\bar{G}_{i}(k)+4 \mu_{i} \epsilon_{i}(k) X_{i}(k)-\bar{G}_{i}^{*}\right\}\right] \\
&-E\left[\left\{G_{i}(k)-G_{i}^{*}\right\}\left\{\bar{G}_{i}(k)-\bar{G}_{i}^{*}\right\}\right] \\
&=-4 \mu_{i}\left(1-4 \mu_{i}\right) E\left[\epsilon_{i}^{2}(k)\right]<0
\end{aligned}
$$

つまり，ステップサイズパラメータに関してつぎのこと が成り立てば, 学習曲線が収束し, 周波数分析を行うこ とができる。

$$
0<\mu_{i}<\frac{1}{4}
$$

\section{3 収束条件}

(10)，(15) 式よりステップサイズパラメータ $\mu_{i}$ がつぎ の条件を満たせば, LMS アルゴリズムが収束し, 周波数 分析を行うことができる。

$$
0<\mu_{i}<\frac{1}{4}
$$

\section{4. 適応離散フーリエ变換法の性能}

適応離散フーリエ変換法の性能をスペクトル分析に必 要なデー夕数, 周波数分解能, 分析精度, 計算量から評 価する。

\section{1 スペクトル分析に必要なデータ数}

LMS アルゴリズムを用いているのでスペクトル分析 に必要なデー夕数はシステムがどの程度で収束するか, つまり, 学習曲線の時定数から求めることができる. $\xi_{i, k}$ は(12)式で与えられ，（9)式を代入するとつぎのように なる。

$$
\begin{aligned}
\xi_{i, k} & =\xi_{i, \min }+2 E\left[C_{i}(k) \bar{C}_{i}(k)\right] \\
& =\xi_{i, \min }+2\left(1-4 \mu_{i}\right)^{2 k} E\left[C_{i}(0) \bar{C}_{i}(0)\right]
\end{aligned}
$$

この式は項比 $\left(1-4 \mu_{i}\right)^{2}$ の等比数列であり, 指数関数で 近似できる. 時定数 $\tau_{i}$ を用いて表わすとつぎのようにな
る.

$$
\left(1-4 \mu_{i}\right)^{2}=\exp \left(-\frac{\Delta T}{\tau_{i}}\right)=1-\frac{\Delta T}{\tau_{i}}+\left\{\frac{\Delta T}{2 ! \tau_{i}}\right\}^{2}-\cdots
$$

ここで, 適応過程があまり速くない場合, つまり, ステッ プサイズパラメータが小さい場合を考えれば，(18)式は つぎのように近似することができる.

$$
1-8 \mu_{i} \simeq 1-\frac{\Delta T}{\tau_{i}}
$$

この式から時定数はつぎのようになる.

$$
\tau_{i}=\frac{\Delta T}{8 \mu_{i}}
$$

つまり, 適応離散フーリエ変換法はステップサイズパラ メータによってフレームの長さを決めることができる.

\section{2 周波数分解能}

まず, ( 6 )式に( 4 ) 式を代入するとつぎのようになる.

$$
\begin{aligned}
G_{i}(k+1)= & G_{i}(k)+4 \mu_{i}[d(k) \\
& \left.-\left\{G_{i} X_{i}(k)+\bar{G}_{i} \bar{X}_{i}(k)\right\}\right] \bar{X}_{i}(k) \\
= & \left(1-4 \mu_{i}\right) G_{i}(k)+4 \mu_{i} d(k) \bar{X}_{i}(k) \\
& -4 \mu_{i} \bar{G}_{i}(k) \bar{X}_{i}^{2}(k)
\end{aligned}
$$

この式とその複素共役の式を考えれば, 入力を $d(k)$, 出 力を $G_{i}(k)$ および $\bar{G}_{i}(k)$ とした Fig. 2 のようなシステ ムとして表わすことができる.フィードバック成分につ いてのみ見れば $\mu_{i}$ の值が小さいとき $\left(1-4 \mu_{i}\right) \gg 4 \mu_{i}$ と なるので, $\bar{G}_{i}(k-1)$ から $G_{i}(k)$, および $G_{i}(k-1)$ から $\bar{G}_{i}(k)$ へフィードバック成分は無視でき, (21) 式はつ ぎのように近似することができる。

$$
G_{i}(k+1) \simeq\left(1-4 \mu_{i}\right) G_{i}(k)+4 \mu_{i} d(k) \bar{X}_{i}(k)
$$

周波数分解能を周波数分析を行っている周波数帯の中心 周波数 $f_{c}$ とそのスペクトル值が $\frac{1}{\sqrt{2}}$ になる周波数 $f_{1}, f_{2}$ の間の幅 $f_{2}-f_{1}$ の比から評価する.

$$
A=\frac{f_{c}}{f_{2}-f_{1}}
$$

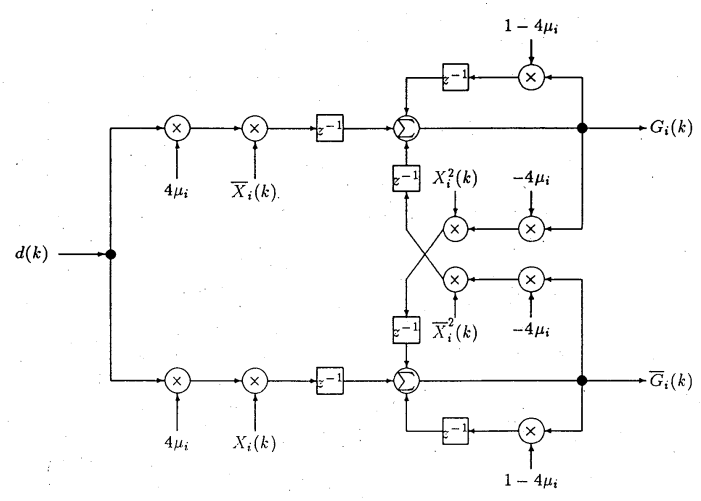

Fig. 2 Block diagram of eq. (15) 
一方，この方法は (21) 式からわかるように入力 $d(k)$ に $\bar{X}(k)=\exp \left(j 2 \pi f_{i} k \Delta T\right)$ を掛けているので, $d(k)$ の周波 数成分を一 $f_{i}$ だけシフトしていることと同值であると 考えることができる．このことから，(22)式から求まる 伝達関数の共振周波数 $f_{r}$ や伝達関数 $H(f)$ の大きさが $\frac{\left|H\left(f_{r}\right)\right|}{\sqrt{2}}$ になる周波数 $f_{1}^{\prime}, f_{2}^{\prime}$ と $f_{c}, f_{1}, f_{2}$ との間にはつぎ のような関係が成り立つと考えられる。

$$
\begin{aligned}
& f_{c}=f_{r}+f_{i} \\
& f_{1}=f_{1}^{\prime}+f_{i} \\
& f_{2}=f_{2}^{\prime}+f_{i}
\end{aligned}
$$

このことから，(23)式はつぎのようになる.

$$
A=\frac{f_{r}+f_{i}}{f_{2}^{\prime}-f_{1}^{\prime}}
$$

ここで，(21)式の伝達関数を考えれば，つぎのようにな る.

$$
H(s)=\left.\frac{4 \mu_{i} z}{\left\{z-\left(1-4 \mu_{i}\right)\right\}\left\{z-\exp \left(j 2 \pi f_{i} \Delta T\right)\right\}}\right|_{z=\exp (s \Delta T)}
$$

$\Delta T$ が十分小さい場合, $z=\exp (s \Delta T)$ はつぎのように 近似することができる.

$$
\begin{aligned}
z & =\exp (s \Delta T)=1+s \Delta T+\frac{1}{2 !}(s \Delta T)^{2}+\cdots \\
& \simeq 1+s \Delta T
\end{aligned}
$$

よって，(28) 式はつぎのように近似することができる.

$$
H(s)=\frac{4 \mu_{i} f_{s}}{\left(s \Delta T+4 \mu_{i}\right)\left(s+j 2 \pi f_{i}\right)}
$$

ここで, $f_{s}$ はサンプリング周波数である.よって, 周波 数分解能はつぎのようになる.

$$
A \simeq \frac{\pi f_{i}}{4 \mu_{i} f_{s}}
$$

つまり, 適応離散フーリエ変換法はステップサイズパラ メー夕 $\mu_{i}$ によって周波数分解能を決めることができる.

\section{3 分析精度}

3.2 節でも述べたように文献 3)で提案した周波数分析 法のように差の 2 乗平均の最小值が零になるとはかぎら ない. また, LMS アルゴリズムを用いているため, 勾配 量の推定值には雑音が含まれ, 多数回の適応を繰り返し ても集合平均的に収束するだけで係数は最適解の近傍で ゆらぎを生じ, 差の 2 乗平均はその最小值より大きく なってしまう。このため, 各周波数成分がどの程度の精 度で求まるかが問題となる，そこで，本論文では，分析 精度を [係数とその最適解の差の分散 $] /[$ 真のスペクトル パワー]で評価することにする。係数とその最適解の差の 分散はつぎのようになる(付録参照)。

$$
E\left[|C(k)|^{2}\right]=2 \mu_{i}\left\{E\left[d^{2}(k)\right]-\left|G^{*}\right|^{2}\right\}
$$

このことから，真のスペクトルパワーによって正規化さ れた係数とその最適解の差の分散 $B$ はつぎのようにな
る.

$$
B=2 \mu_{i}\left\{\frac{E\left[d^{2}(k)\right]}{\left|G^{*}\right|^{2}}-1\right\}
$$

つまり, 適応離散フーリエ変換法における分析精度はス テップサイズパラメータに比例し，真のスペクトルパ ワーの 2 乗に反比例する.このことから，真のスペクト ルパワーが小さい場合でもステップサイズパラメータを 小さな值にすれば，精度良く分析が可能であると考えら れる。

\section{4 計算量}

採譜や音声分析を考えた場合，適応離散フーリエ変換 法では，逐次計算によって周波数分析を行わなくてはな らない．同様のことをFFTで行うには観測空をある間 隔でシフトさせていき周波数分析を行う必要がある。1 回の FFT に必要な乗算回数と適応離散フーリエ変換法 での 1 回の逐次計算に必要な乗算回数の比が FFT の観 測空をシフトさせていく間隔に等しいとき，全処理に必 要な乗算回数が等しくなるので乗算面では同等となると 考えることができる.

\section{4.1 適応離散フーリエ変換法}

乗算回数を減らすために 1 周期の $\sin ま た は ~ \cos$ 関数 を $N\left(=2^{n}\right)$ 等分したテーブルを作成し，その番地を呼び 出す方法を用いることにする．分析する周波数をある周 波数 $\left(\frac{1}{N}\right)$ の整数倍 $k$ で近似すれば $X_{i}(k)$ は；呼び出す 番地を $k$ ごと逐次シフトしていくことによって求める ことができ，乗算を必要としない．このことから一つの 周波数成分を分析するのに必要な乗算回数は ( 7 )式で 3 回, (6)式の適応過程で 2 回の計 5 回である. $M$ 個の周 波数分析をするのに必要な乗算回数 $C$ はつぎのように なる.

$$
C=5 M
$$

4.4.2 FFT 法

$L$ 点FFTでは 1 フレームあたり FFTに $2 L \log _{2} L$, 空掛けに $L$ の乗算が必要であり, 乗算回数 $D$ はつぎの ようになる。

$$
D=2 L \log _{2} L+L
$$

採譜への応用を考えれば，各音素の基本周波数を求め ることが目的であるので，第 2 オクターブから第 5 オク ターブまでの 48 点の周波数成分で周波数分析を行えば 良いと考えられ，適応離散フーリ工変換法では 1 回の逐 次計算に必要な乗算回数は 240 回となる.よって, 512 点 FFT を用いる場合ではFFT のフレーム周期が 40 点で あれば同じ乗算回数になると考えることができる. 


\section{5. 実験}

\section{1 採譜への応用}

楽器が奏でる音の音階の同定精度を向上させるには周 波数分析精度を向上するとともに信号の変化に対する追 随性を向上させなくてはならない. 文献 3)で提案した周 波数分析法では係数べクトルの数 $L$ が多くなると信号 に対する追随性が損なわれるという問題点がある。しか し，適応離散フーリエ変換法は分析する周波数の数に影 響されないのでこのような問題点は生じないと思われ る。そこで，音の音階の同定比較を行う．同定手順はつ ぎのような点を考慮に入れた文献 5)の方法を用いる. 文 献5)で述べたように周波数分析によって得られた各音 階の周波数成分にはインパルス状のノイズを生じること があり，精度を向上させるにはこのようなノイズを除去 しなくてはならない。楽器が奏でる音には基本波成分と 高調波成分を含んでいる。よって，和音を扱う場合，周 波数分析で得られたピーク周波数が実際に演奏されだ音 の基本波成分なのか，ほかの音の高調波成分であるのか を決めなくてはならない. その結果を Fig. 3 と Table 1 に示す. Fig. 3 は周波数分析法によって得られた周波数 成分に対してインパルス状のノイズを除去し，高調波成 分を除去することによって得られたパワースペクトル マップである。このように適応離散フーリ工変換法は文 献 3)で提案した周波数分析法よりも音の同定精度は 2 . $5 \%$ 程度向上した。これは, Fig. 3 からわかるように本論 文で提案した方法のほうが音の立ち上がりに対する追随 性が良いことが原因として考元られる。実際に Fig. 3 亿 おいて 10000 点付近で文献 3)で提案した周波数分析法 では G4 の音の立ち上がりが遅く，C5 の前フレームから の継続音の值が小さくなりすぎてしまい誤認識をしてし まった.しかし, 適応離散フーリエ変換法では G4 の音の 立ち上がりが速く誤認識がなかった。

しかし，上述のように和音を扱う場合，同定精度を向 上させるためには，ピーク周波数が実際に演奏された音 の基本波成分なのか，ほかの音の高調波成分であるのか を決めなくてはならない，そこで，文献5)の手順のよう に基本波成分と高調波成分のパワーの比のテーブルを用 意しておき，基本波成分のパワーをその基本波成分がも つ高調波成分のパワーを加えたものとして高調波成分の 除去を行い，音階の同定することが有効な方法の一つで あると考光られる。しかし，基本波成分と高調波成分の パワーの比は変動し, 変動の仕方は楽器の種類や基本周 波数によって異なるので，より音階の同定精度を向上さ せるにはその変動の仕方を記憶しなくてはならない。し かし，実際のシステムを考えれば，メモリの制約から変

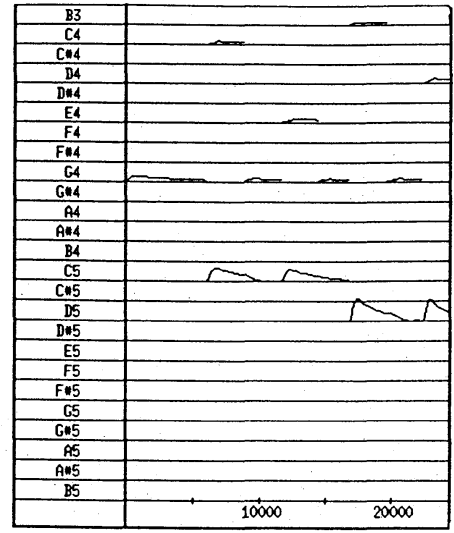

(STEP)

(a) proposed method

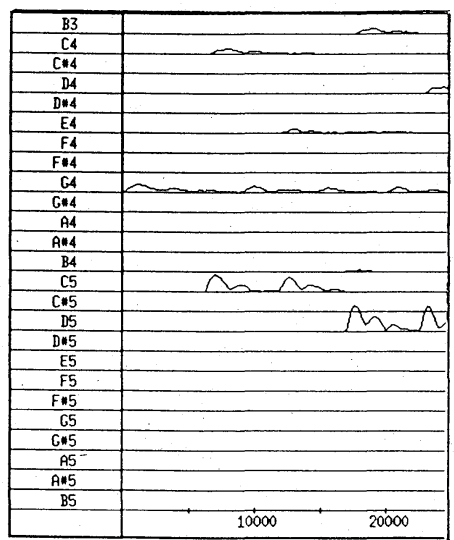

(STEP)

(b) conventional method (ref. 3)

Fig. 3 Power spectra map after high frequency absorption

Table 1 Accuracy of transcription

\begin{tabular}{c|c|c}
\hline \hline Music & $\begin{array}{c}\text { Proposed } \\
\text { method }\end{array}$ & $\begin{array}{c}\text { Conventional } \\
\text { method } \\
\text { (Ref. 3) }\end{array}$ \\
\hline Musunde hiraite & $90.7 \%$ & $90.7 \%$ \\
\hline Izumi no hotori & $92.0 \%$ & $91.5 \%$ \\
\hline Tanigawa no nagare & $97.3 \%$ & $95.1 \%$ \\
\hline Ogawa no suisya & $94.5 \%$ & $92.4 \%$ \\
\hline Kari & $92.3 \%$ & $90.4 \%$ \\
\hline Daisukina warutu & $95.2 \%$ & $90.5 \%$ \\
\hline Yogisya & $93.4 \%$ & $91.0 \%$ \\
\hline Merisan no hituji & $92.8 \%$ & $92.6 \%$ \\
\hline Yama no ongakuka & $92.0 \%$ & $88.3 \%$ \\
\hline Average & $93.7 \%$ & $91.3 \%$ \\
\hline
\end{tabular}


動する基本波成分と高調波成分とのパワーの比を平均化 したテーブルを用いなくてはならない.このことが, 本 論文の方法でも $94 \%$ 程度の精度になった原因の一つで あると考えられる。

\section{2 音声の分析への応用}

実際の音声信号のスペクトル分析を行い, 本論文で提 案する周波数分析法が音声分析に有効な方法であること を確かめる. 音声信号はディジタルオーディオテープ (DAT) を用い録音したディジタルデータをDAT インタ フェースボードを用いて $24 \mathrm{kHz}$ にダウンサンプリング し,コンピュータに取り込んだものを用いた。人間の聴 覚特性は低周波数領域では周波数分解能が良く, 周波数 が高くなるにつれて悪くなるといわれている 分析には, 1オクターブあたり 100 チャネル程度の高分 解能周波数分析法が必要であるという報告もある21.こ のことから, 本論文では, 周波数分析は $156 \mathrm{~Hz}$ から 5 $\mathrm{kHz}$ までの 5 オクターブを，1オクターブあたり 100 , 全 500 チャネルで行った. よって, 各チャネルの分析周 波数はつぎのようになる.

$$
f_{i}=0.0065 f_{s} \cdot 2^{\frac{(i-1)}{100}} \quad(i=1,2, \cdots, 500)
$$

音声を分析する場合, スペクトル包絡を求め, その包 絡線から分析することが有利である。このことから尖鋭 度が高くなるような周波数分析法は音声分析には向かな い. 本論文で求めた周波数分解能を評価するパラメータ A は尖鋭度を表わすパラメータでもある.このパラメー タ $A$ はステップサイズパラメータによって決めること ができるので, 尖鋭度が高くならないようにステップサ イズパラメータはつぎに示すようなものを用いた。

$$
\mu_{i}=0.0008+\frac{i}{38000}
$$

このことによってパラメータ $A$ は第 1 チャネル(分析 周波数 $156 \mathrm{~Hz}$ ) で 6.4 , 第 250 チャネル(分析周波数 852 $\mathrm{Hz}$ ) で 8.3, 第 500 チャンネル(分析周波数 $4820 \mathrm{~Hz}$ )で 26.6 とゆるやかに増加させることができる. 成人男性の 発声による単音節 $/ \mathrm{nu} /$ の結果を Fig. 4 に示す. Fig. 4

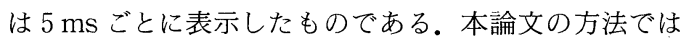
高い分析周波数のチャネルではピッチよりも時定数が短 くなり,フーリエ係数 $G_{i}(k)$ がピッチに同期して変動し てしまうので, その影響を減らすために空幅 $10 \mathrm{~ms}$ の方 形空に通し, 平滑化処理を施した。

この結果からわかるように音節/nu/ における子音 $/ \mathrm{n} /$ の特徵である子音から母音へのわたり区間における 第 2 フォルマント $\left(F_{2}\right)$ の高い周波数側から低い周波数 側への移動が顕著に現れている.また, /u/ の $F_{2}$ 付近で は時定数が $1.3 \mathrm{~ms}$ 程度と短く設定でき, 破裂音などのよ うに時間変動の速い音声のスペクトル変動の観測に有利

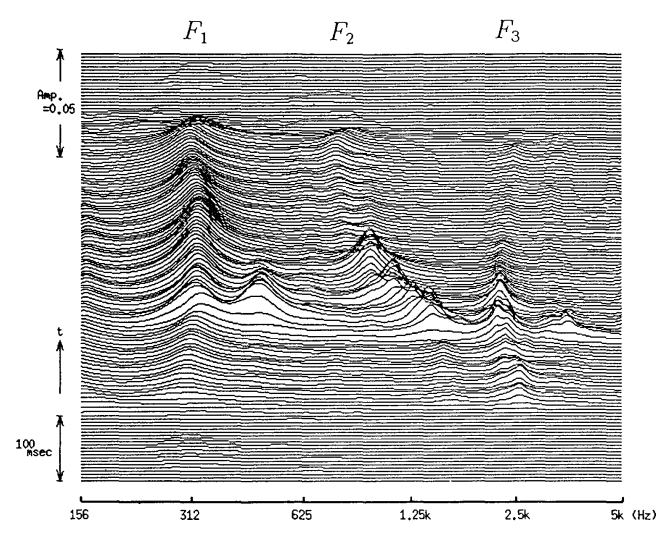

Fig. 4 Running spectra of /nu/ analyzed by the proposed method

な方法であるといえる.

\section{6. 結 論}

本論文では, 文献 3)で提案した周波数分析法を各周波 数成分ごとに分割し，各成分ごとに LMS アルゴリズム を適用した適応離散フーリ工変換法を提案し, その収束 条件を求めるとともに, 種々の性能の検討を行った. こ の周波数分析法は文献 3)で提案した周波数分析法のよ うに分析しなくてはならない周波数の数 $L$ の影響を受 けないので，広帯域の音階の同定を考える場合には有利 であると考えられる.また,スペクトル分析に必要なデー 夕数, 周波数分解能, 分析精度などはステップサイズパ ラメータの值に依存する.このことからステップサイズ パラメータの值を適切に選定することのよって精度の良 い周波数分析法にもなるし, 任意の分析間隔・フレーム 長でのスペクトル分析を行うこともでき，採譜への応用 だけではなく音声分析にも適した周波数分析法であると 考えられる。

\section{参 考 文 献}

1) J. B. Allen: Short Term Spectra Analysis, Synthesis and Modification by Discrete Fourier Transform, IEEE Trans., ASSP-25-3, 235/238(1977)

2) 原田, 河原田: 音声の高分解能周波数分析 $-/ \mathrm{mi} /, / \mathrm{ni} /$ の 特徵抽出-, 信学論 (A), J69-A-5, 620/627 (1969)

3）梅本，青島：適応技術を用いた採譜に有効な周波数分析 法, 計測自動制御学会論文集, 28-5, 619/625(1992)

4）梅本, 青島：適応フィルタを用いた周波数分析法における ステップサイズパラメータの選定, 計測自動制御学会論文 集, 28-10, 1257/1262(1992)

5）梅本, 青島：採譜システムの構築と音高抽出精度の比較, 計測自動制御学会論文集, 29-10, 1227/1231(1993)

6) 三浦種敏：聴覚と音声, 電子通信学会 (1980)

7) B. Widrow and S. D. Stearns : Adaptive Signal Processing, 195, Prentice Hall Inc. (1985) 


\section{《付録 係数と艺の最適解の差の分散の導出》}

係数とその最適解の差の分散はWidrow らによって 導出されている7).この手順に従って, 適応離散フーリエ 変換法における係数とその最適解の差の分散の導出を行 う。まず, LMS アルゴリズムにおける勾配量 $\hat{\nabla}(k)$ は, 真の勾配量 $D(k)$ にノイズ $N(k)$ を含んだものであると 考えられ，つぎのように表わすことができる.

$$
\hat{\nabla}(k)=\nabla(k)+N(k)
$$

係数がその最適解に十分収束した場合を考えれば, $\nabla(k)$ は $N(k)$ に比べ十分に小さくなるので, 上式はつぎのよ うになる。

$$
\hat{\nabla}(k)=N(k)=-4 \mu_{i} \bar{X}_{i}(k)
$$

このことから, $\hat{\nabla}(k)$ に含まれる $N(k)$ の分散はつぎのよ うになる。

$$
\begin{aligned}
E\left[|N(k)|^{2}\right] & =E[N(k) \bar{N}(k)] \\
& =16 E\left[\epsilon^{2}(k)\right] E[X(k) \bar{X}(k)] \\
& =16 E\left[\epsilon^{2}(k)\right] \\
& \simeq 16 \xi_{i, \min }
\end{aligned}
$$

つぎに係数とその最適解の差の分散を考える.まず, ( 6 ) 式の両辺から最適解 $G_{i}^{*}$ 引くとつぎのようになる.

$$
C_{i}(k+1)=C_{i}(k)-\mu_{i} D(k)-\mu_{i} N(k)
$$

$\nabla(k)$ はつぎのようになる.

$$
\nabla(k)=\frac{\partial E\left[\epsilon^{2}(k)\right]}{\partial G_{i}(k)}
$$

$$
\begin{aligned}
& =4\left\{G_{i}(k)-E\left[d(k) \bar{X}_{i}(k)\right]\right\} \\
& =d\left\{G_{i}(k)-G_{i}^{*}\right\} \\
& =4 C_{i}(k)
\end{aligned}
$$

よって，(39)式はつぎのようになる.

$$
C_{i}(k+1)=\left(1-4 \mu_{i}\right) C_{i}(k)-\mu_{i} N(k)
$$
このことから, $C_{i}(k)$ と $N(k)$ が統計的に独立であると すれば，つぎのようになる。

$$
\begin{aligned}
E\left[|C(k+1)|^{2}\right]= & \left(1-4 \mu_{i}\right)^{2} E\left[|C(k)|^{2}\right] \\
& +\mu_{i}^{2} E\left[|N(k)|^{2}\right]
\end{aligned}
$$

$\mu_{i}$ が十分小さく, 係数がその最適解に十分収束した場 合, $E\left[|C(k+1)|^{2}\right] \simeq\left(1-4 \mu_{i}\right)^{2} E\left[|C(k)|^{2}\right]$ と考えることが できるので, 上式はつぎのようになる.

$$
\begin{aligned}
E\left[|C(k)|^{2}\right] & =\frac{\mu_{i}}{8\left(1-2 \mu_{i}\right)} E\left[|N(k)|^{2}\right] \\
& \simeq 2 \mu_{i} \xi_{i, \min }
\end{aligned}
$$

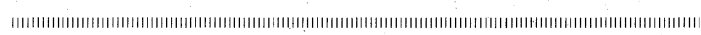

\section{[著 者 紹 介]}

梅 本 敏 孝 (学生会員)

（本号 p. 942 参照）

青 島 伸 治 (正会員)

(Vol. 30, No. 2 参照) 